\title{
KONSTRUKSI KEPEMIMPINAN DALAM RUMAH TANGGA ISTRI PENCARI NAFKAH UTAMA DALAM BINGKAI HUKUM ISLAM DAN HUKUM POSITIF DI KOTA BENGKULU
}

\author{
Zurifah Nurdin \\ IAIN Bengkulu \\ zurifahnurdin@gmail.com
}

\begin{abstract}
This research was motivated by the husband's unpreparedness and unwillingness to fulfill a living for his wife and children, even though the responsibility of living is assumed by him. The wife was used as an ATM for the husband so that he becomes a colonized creature both physically and mentally. Islamic law and positive law uphold benefits in order to achieve justice, therefore positioning the wife as the main breadwinner and leader even head of the family is legitimate based on the theory of maslahah al mursalah and maqashid asyari'ah. The husband will be positioned as a leader if he fulfills a living for his wife and children, both inner and outer..
\end{abstract}

Keywords: Wife, Husband and Leader.

\begin{abstract}
Abstrak. Penelitian ini di latarbelakangi oleh ketidak siapan dan ketidak mauan suami memenuhi nafka untuk istri dan anak-anaknya, padahal tanggungjawab nafkah dibebankan padanya. Istri dijadiakan ATM berjalan bagi suami sehingga istri menjadi makhluk yang terjajah baik lahir maupun batin. Hukum Islam dan Hukum positip menjujung tinggi kamaslahatan dalam rangka mengapai keadilan, oleh karena itu memposisikan istri pencari nafkah utama sebagai pemimpin dan kepala keluarga adalah syah berdasarkan teori maslahah al mursalah dan maqashid asyari'ah. Suami akan diposisikan sebagai pemimpin jika memenuhi nafkah bagi istri dan anak-anaknya, baik nafkah lahir maupun batin.
\end{abstract}

Kata Kunci: Istri, Suami dan Pemimpinan.

\section{Pendahuluan}

Laki-laki sebagai pemimpin bagi kaum perempuan dijelaskan dalam Nash Al Qur'an, ${ }^{1}$

Kaum laki-laki itu adalah pemimpin bagi kaum wanita”

\footnotetext{
${ }^{1}$ Al Qur'an surat Al-Nisã' ayat 34
} 
Suami dalam rumah tangga adalah kepala keluarga, ${ }^{2}$ suami merupakan pembimbing istri dan anak-anaknya, serta mengenai urusan rumah tangga diputuskan oleh suami, suami yang mencari nafkah dan mengatur keluarga. ${ }^{3}$ Para lelaki, atau suami adalah pemimpin dan penanggung jawab atas istri, suami bertanggung jawab atas menafkah istri dengan dimulainya pembayaran mahar dan untuk selanjutnya bertanggung jawab atas biaya hidup untuk istri dan anakanaknya. ${ }^{4}$ Kata pakaian dalam ayat al -Qur'an majaz atau kiasan yang intinya harus saling menolong, menutupi kekurangan dan kelebihan masing-masing, sehingga terbangunlah keluarga yang kokoh. ${ }^{5}$ Ketetapan hukum semacam ini bukanlah wujud dari sikap otoriter, akan tetapi merupakan bentuk keadilan yang ditetapkan oleh Allah swt yang telah menciptakan laki-laki dan wanita berdasarkan atas fitrah masing-masing. Nafkah merupakan tanggungjawab suami sebagaimana firman Allah swt;

Hendaklah orang yang mampu memberi nafkah menurut kemampuannya. dan orang yang disempitkan rezkinya hendaklah memberi nafkah dari harta yang diberikan Allah kepadanya.

Kekhususan peran laki-laki dan perempuan itu semata-mata merupakan pembagian tugas yang dipandang sama-sama penting dan bersifat saling melengkapi demi kehidupan yang stabil. ${ }^{7}$ Namun dalam kenyataaan bahwa

2 Pengertian keluarga adalah sanak saudara, kaum kerabat, seisi rumah, ibu bapak, anak-anaknya, orang-orang seisirumah yang menjadi tanggungan, atau satuan kekerabatan yang sangat mendasar. Lihat Departemen Pendidikan dan Kebudayaan, Kamus Besar bahasa Indonesia,(Jakarata; Balai Pustaka. 1988), h. 413 dan W.J.S Poerwadarminta, Kamus Umum Bahasa Indonesia, (Jakarta: Balai Pustaka, 1985), h. 470. Keluarga juga diartikan dua orang atau lebih yang hidup bersama, yang mempunyai hubungan darah, perkawinan atau karena pengangkatan. Bisri Mustofa dan Elisa Vindi Maharani, Kamus Lengkap Sosiologi, (Jogjakarta; Panji Pustaka, 2008), h. 103. Dan dalam Undang-undang Nomor 10 Tabun 1992 tentang kependudukan dan Keluarga Sejabtera Bab Ketentuan Umum, menjelaskan bahwa keluarga merupakan unit (Lembaga) terkecil dalam masyarakat yang terdiri dari suami dan istri , atau suami istri dan anaknya, atau ayahnya dengan anaknya, atau ibu dengan ayahnya. Adapun hidup berkeluarga adalah kehidupan bersama dua orang lawan jenis yang bukan mahramnya yang telah mengikatkan diri dengan tali perkawinan beserta anak keturunannya yang dihasilakn dari akibat tersebut. Pengertian keluarga memiliki dua dimensi; pertama, keluarga sebagai ikatan kekerabatan antar individu, ini merujuk pada hubungan darah dan perkawinan. Kedua "rumah tangga" dalam makna ini ikatan kekerabatan amat penting, namun yang menjadi penekanan adalah kesetuhunian dan ekonomi. Sedangkan dalam al Qur'an surat Thaha:132 dan surat al Tahrim: 6, keluarga diistilahkan dengan al Ablu (Famili, keluarga dan kerabat).

3 Undang-undang No 1 Tabun 1974 dan dalam Kompilasi Hukum Islam pasal 79 dinyatakan bahwa suami adalah kepala keluarga dan istri ibu rumah tangga. hlm: 422-423

${ }^{4}$ M. Quraish Shihab, Tafsir Al-Mishbah Pesan, Kesan dan Keserasian Al-Qur'an vol. 2...

5 Azyumardi Azra dan Abudin Nata, Kajian Tematik, Al-Qur'a $>n$ tentang Kemasyarakatan (Bandung: Angkasa, 2008) hlm: 191

${ }^{6}$ Al Qur'an Surat At Thalak: 7

7 Al Qur'an Surat An Najm ayat 45 dan At Taubah ayat 71 
perempuan sering dipandang dan diperlakukan tidak manusiawi, seperti banyak dalam keluarga yang mencari nafkah adalah perempuan akan tetap yang menguasai harta kekayaan adalah laki-laki, perempuan harus setor pendapatannya pada suaminya, istri tidak diperboleh mempergunakan hasil pendapatannya dan bahkan jika terjadi perceraianpun istri hanya mendapatkan pembagian harta yang sangat sedikit dibanding laki-laki apalagi kalau yang menggugat cerai adalah perempuan maka jangan harap akan mendapatkan pembagian harta, ketidak adilan ini sering terjadi di masyarakat.Nilai-nilai dan norma-norma yang tertuang dalam ajaran Islam telah direkonstruksi melaui proses dialektika pemahaman manusia untuk melahirkan suatu sistem dalam sosio cultural masyarakat. Sistem inilah yang mengatur dan membimbing perilaku manusia dalam menjalankan roda kehidupan. Sehingga apapun aktivitas umat muslim tidak boleh terlepas dari nilai-nilai Ketuhanan (Aqidah), begitupun dalam melaksanakan aturan-aturan dalam hukum adat.Kewajiban seorang suami mencari dan memberi nafkah dalam keluarga sehingga ia mendapatkan hak sebagai pemimpin dan jika kewajiban nafkah tidak terlaksanakan maka haknya sebagai pemimpin perlu dipikirkankan ulang agar perempuan pencari nafkah mendapatkan haknya dan keadilan dimata hukum, baik hukum Islam maupun peraturan perudang-undangan yang berlaku di Indonesia.

Di kota Bengkulu fenomena istri pencari nafkah utama dan suami tetaplah pemimpinan dan berkuasa terhadap harta, istri padahala dia tidak melakukan kewajiban sebagai pemberi nafkah banyak sekali terjadi, oleh karena itulah peneliti sangat ingin mengetahui bagaimana konstruksi kepemimpinan dalam rumah tangga yang istrinya pencari nafkah utama. Sehinga peneliti menganngkat judul penelitian "Konstruksi Kepemimpinan dalam Rumah Tangga Istri Pencari Nafkah Utama dalam Bingkai Hukum Islam dan Perundang-undangan yang berlaku di Indonesia di Kota Bengkulu. Rumusan Permasalahan

Adapun rumusan masalahnya adalah Bagaimana pemahaman masyarakat terhadap kepemimpinan dalam rumah tangga bila sang istri adalah pencari nafkah utama. Bagaimana pembagian harta jika terjadi perceraian dalam keluarga yang istri pencari nafkah utama. Bagaimana konstruksi kepemimpinan dalam rumah tangga yang istri sebagai pencari nafkah utama.Sedangkan Tujuannya adalah untuk mengetahui bagaimana pemahaman masyarakat tentang kepemimpinan dalam rumah tangga yang istri adalah pencari nafkah utama.Pola kekuasaan suami yang istrinya pencari nafkah utama dalam rumah tangga.Untuk mengetahui konstruksi kepemimpinan dalam keluarga si istri pencarai nafkah utama di kota Bengkulu.

\section{Pembahasan}




\section{Pemahaman Masyarakat Tentang Kepemimpinan Dalam Rumah Tangga}

Sebalas informan menyatakan bahwa suami tetaplah sebagai pemimpin keluarga dan kepalah rumah tangga walaupun suami tidak melaksanakan kewajiban sebagai pemberi nafkah, walaupun istri merupakan pencari nafkah utama bagi keluarga namun peminpin dan kepalah keluarga tetap suami. Ini artinya mayoritas masyarakat kota Bengkulu pada hakekatnya sangat menjunjung tinggi kedudukan suami sebagai pemimpin dan kepalah rumah tangga, pemahaman masyarakat kota Bengkulu ini dipengaruhi oleh kultur yang melekat pada suku Melayu yang bersistemkan kekerabatan patrilineal.

Menurut Ilmu sosiologi-antropologi atau Etnologi ada tiga bentuk kongkrit sistem kekerabatan yang hidup dalam masyarakat, yang meliputi susunan patrilineal, matrilineal dan bilateral. ${ }^{8} \mathrm{Pada}$ aspek patrilineal sistem kekeluargaan yang dibangun adalah dengan menguatkan garis keturunan ayah sebagai penentu segala kebijakan di dalam keluarga, dan dalam hukum perkawinan berlaku pembayaran jujur, dimana setelah perkawinan istri melepas kewargaan adat dari kerabat ayahnya dan memasuki adat kerabat suaminya, untuk itulah maka kedudukan suami selanjutnya lebih tinggi dari hak dan kedudukan istri.' Selain dipengaruhi oleh kultur kekerabatan juga dipengaruhi oleh keyakinan atau agama yang mereka anut, yakni mayoritas masyarakat kota Bengkulu beragama Islam. Dalam Islam dinyatakan bahwa suami adalah pemimpin keluarga, QS. Al- Nisã’: 34 Ada 2 Tanggung jawab suami terhadap keluarga yaitu menafkahi keluarga. Suami sebagai qowamah atau pemimpin keluarga tidak lepas dari tanggungjawab dan hak sebagai seorang pemimpin. Kedua permasalan ini ibarat dua lengan timbangan, yang beban kiri dan kanan haruslah imbang, jika tidak maka akan "njomplang", seorang suami haruslah mendahulukan tanggung jawabnya, ini ibarat anak timbangan, maka hak akan menyusul kemudian ini ibarat zat yang akan ditimbang, jadi berat ringannya hak suami akan sangat tergantung dengan anak. Dan dalam Hadis dinyatakan.$^{10}$

Laki- laki adalah pemimpin bagi wanita yang bersifat komprehensif, pemimpin yang dapat melindungi anggota keluarganya, pemimpin yang dapat mentarbiyah keluarganya, pemimpin yang dapat mengarahkan, mendamping membantu menjaga, mengawasi anggota keluarganya sehingga keluarga tersebut dapat berjalan dengan harmonis menuju tujuan hidup.

Laki- laki dipilih oleh Allah swt sebagai pemimpin rumahtangga dan pemimpin bagi kaum wanita secara umum karena tabi'at perempuan yang 1993),. h 144

8 Amir Syarifuddin, Pembaharuan Pemikiran Hukum Islam, (Padang: Angkasa Raya,

${ }^{9}$ Hilman Hadikusuma, Hukum Kekerabatan Adat, (Jakarta: Fajar Agung, 1993),. h. 144

10 " HR: Imam Muslim Nomor 3428 
lemah lembut, mudah terbawa arus perasaan, yang mengandung dan menyusui, serta merawat anak, sangatlah tidak relevan jika wanita dibebani sebagai pemimpin bahtera rumah tangga yang begitu besar dan berat. Seorang suami bertanggung jawab penuh terhadap istri dan keluarganya, yang dipertanggung jawabkan ke hadapan Allah swt bukan hanya kebaikan dan amal dari anggota keluarga tetapi juga kesalahan dan dosa dari anggota keluarga tersebut. Inilah sebabnya yang kemudian bahwa Allah swt memberikan pahala berlimpah pada seorang suami berupa pahala sebagai seorang pemimpin "Qowwam " dalam sebuah keluarga. Islam dan peraturan perundang undangan tentang perkawinan yang berlaku di Indonesia menyatakan bahwa suami adalah pemimpin dan kepala keluarga yang mempunyai kewajiban yang meliputi, mencari nafkah, menguasai harta, pembimbing istri dan anak-anaknya, mengenai urusan rumah tangga diputuskan oleh suami sebab suami yang mencari nafkah dan mengatur keluarga ${ }^{11}$ menurut Islam dan hukum positif suami yang telah memenuhi kebutuhan nafkah dan perlindungan sebagaimana tersimpul dalam kewajiban suami berhak menjadi pemimpin yang mempunyai otoritas yang kuat. Pasal 106 dinyatakan bahwa setiap istri harus tunduk dan patuh pada suaminya. ${ }^{12}$ Oleh karena itu kepemilikan dan kekuasaan harta oleh suami karena suami mempunyai kepemilikan terhadap nafkah.

Suami wajib melindungi istrinya dan memberikan segala sesuatu kepentingan hidup berumah tangga sesuai dengan kemampuannya. ${ }^{13}$ Lalu pada aturan yang lain menjelaskan bahwa suami wajib melindungi istri dan memberikan segala sesuatu keperluan hidup berumah tangga sesuai dengan kemampuannya, suami wajib memberi pendidikan agama kepada istrinya dan memberi kesempatan belajar pengetahuan yang berguna lagi bermanfaat bagi agama, nusa dan bangsa. ${ }^{14}$ Tempat kediaman yang disediakan untuk melindungi istri dan anak-anaknya dari gangguan pihak lain, sehingga mereka merasa aman dan tentram. Suami wajib melengkapi tempat tinggalnya, baik berupa alat perlengkapan rumah tangga maupun sarana penunjang lainnya. ${ }^{15}$ Rasulullah saw bersabda.

Dari Hakim bin Mu'awiyah, dari ayahnya, dari Nabi saw. Berkata Mu'awiyah; seorang laki-laki bertanya kepada Nabi saw tentang hak seorang istri. Nabi saw menjawab; engkau harus memberinya makan jika engkau mendapat makan, memberinya pakaian, jangan memukul wajahnya dan jangan

${ }^{11}$ Undang-Undang No 1 Tabun 1974 pasal 31 dan Kompilasi Hukum Islam pasal 79 dinyatakan bahwa suami adalah kepala keluarga dan istri ibu rumah tangga.

12 Subekti, R Tjitrosudibio, Kitab Undang-Undang Hukum Perdata, Burgerlijk Wetboek dengan tambahan Undang-undang Pokok Agraria dan Undang-undang Perkawinan, (Jakarta, Pt Pradnya Paramita, 1992) pasal 105-106

${ }^{13}$ Undang-Undang No 1 tahun 1974 Tentang Perkawinan pasal 32 ayat 1 dan pasal 35 ayat 1

${ }^{14}$ Kompilasi Hukum Islam pasal 80-81

${ }^{15}$ Ibid pasal 82 
meninggalkan mereka kecuali ia berada di rumah. HR. Ahmad, Abu Daud dan Ibn Majah ${ }^{16}$

Dari Abi Hurairoh, Rasulullah saw bersabda; Seorang mukmin tidak boleh membenci seorang mukminah. Jika ada satu perangai yang tidak disukainya, maka ada perangai lain yang di sukainya, atau ia akan berkata lain. HR. Muslim dan Ahmad ${ }^{17}$

Mengenai nafkah tercantum juga dalam Undang-Undang RI nomor 1 tahun 1974 tentang perkawinan Bab VI mengenai Hak dan Kewajiban Suami Istri Pasal 34 ayat 1 sampai 3 yang berbunyi: a. Suami wajib melindungi istrinya dan memberikan segala keperluan hidup berumah tangga sesuai dengan kemampuannya. b. Istri wajib mengatur urusan rumah tangga sebaik-baiknya. c. Jika suami atau istri melalaikan kewajiban masing-masing dapat mengajukan gugatan kepada pengadilan.

\section{Kekuasaan Istri Pencari Nafkah Utama Dalam Rumah Tangga}

Istri pencari nafkah utama dalam keluarga di kota Bengkulu dalam data yang peneliti dapatkan mayoritas istri pencari nafkah utama tidak mempunyai kekuasaan dan keluasan dalam mengurus rumah tangga, khusus dalam pengelolaan, pengaturan keuangan dalam rumah tangga dan bahkan dalam berpendapat. Istri pencari nafkah utama dalam keluarga kurang mempunyai kekuasaan dikarenakan kedudukan suami yang diktator yang tidak paham kewajibannya. Padahal jelas dalam berbagai teori menyatakan bahwa nafkah sangat erat hubungannya dengan kewajiban suami, nafkah merupakan belanja untuk hidup; (uang) pendapatan: suami wajib memberi bekal hidup sehari-hari kepada istrinya kepada istrinya baik nafkah batin maupun jasmani. Sebuah Hadis Rasulullah. ${ }^{18}$ yang menceritakan tentang Hindun binti Utbah pernah datang menemui Rasulullah saw mengadukan kesulitannya karena suaminya tidak memberikan nafkah yang cukup untuknya dan anak-anaknya. Ia terpaksa mengambil harta suaminya tanpa sepengetahuannya untuk mencukupi kebutuhan. Maka Rasulullah saw bersabda

"Ambillah (dari harta suamimu) apa yang mencukupimu dan anak-anakmu dengan cara yang baik"

16 Ahmad dalam kitab Musnad al-Basariyyin, hadis no 19160 dan 19162. Abu Daud dalam kitab nikab hadis No 1830 dan hadis no 1831 sedangkan Ibn Majah dalam kitab Nikab hadis no 1840. Kewajiban memberikan nafkah juga diatur dalam UU no 1 tahun 1974 pasal 34 ayat 1 "Suami wajib melindungi istrinya dan memberikan segala sesuatu keperluan hidup berumah tangga sesuai dengan kemampuannya, istri wajib mengatur urusan rumah tangga sebaik-baiknya. Jika suami atau istri melalaikan kewajibannya masing-masing dapat mengajukan gugutan kepada pengadilan." Dan KHI pasal 80 ayat 4 "Sesuai dengan penghasilannya suami menanggung, nafkah, kiswah, dan tempat kediaman bagi istrinya, biaya rumah tangga, biaya perawatan, dan biayah pengobatan bagi istri dan anaknya. Biaya pendidikan bagi anaknya.

${ }^{17}$ Muslim kitab al-Rodho'ah hadis no 2672 dan Ahmad dalam kitab al-Muktasirin hadis no 8013

18. HR Bukhari dan Muslim dan selain keduanya 
Adapun penyebab diwajibkannya nafkah oleh suami atas istrinya dikarenakan adanya pernikahan yang sah, karena nafkah merupakan konsekuensi terjadinya suatu aqad antara seorang pria dengan seorang wanita. (tanggung jawab seorang suami dalam rumah tangga/keluarga), suami dihalalkan menimati atasnya dan istripun wajib mentaati suaminya dan sebagai penyeimbang itu semua, maka suami wajib mencukupi kebutuhan istri semala hubungan suami istri itu ada. ${ }^{19}$ Nafkah sangat erat hubungannya dengan kewajiban suami, maka nafkah merupakan belanja untuk hidup; (uang) pendapatan: suami wajib memberi kepada istrinya dan bisa juga diartikan bekal hidup sehari-hari. Dan yang dimaksud dengan nafkah batin nafhkah untuk memenuhi kebutuhan batin.

Aturan interaksi laki-laki dan perempuan ini sangat dibutuhkan manusia, sebab manusia mempunyai suatu fitrah yang khas dibanding makhluk yang lain. Kedua jenis ini tidak dapat dibedakan dari aspek kemanusiaannya, oleh karenanya Allah Swt dalam penciptaannya telah menganugerahkan akan potensi dinamis sebagai kebutuhan hidup baik berupa dorongan jasmani, seperti lapar, dan potensi naluria atau insting seperti mempertahankan diri. Selain itu Allah swt juga memberikan manusia kekuatan untuk berfikir yakni akal yang ada pada perempuan ataupun laki-laki, dengan akal manusia dapat melakukan pilihanpilihan sekaligus mencapai efektivitas kesempurnaan hidup.

Perempuan dan laki-laki diciptakan Allah swt sebagai mitra yang saling membutuhkan sebab tidak mungkin seorang perempuan merasa tidak butuh kepada laki-laki sebagai mendampinginya meskipun si perempuan mempunyai kedudukan yang tinggi, harta yang melimpah ataupun intelektual yang tinggi. Begitu juga seorang laki-laki tidak mungkin tidak membutuhkan perempuan yang mendampinginya. Suami dan istri diberi tanggungjawab untuk melestarikan manusia dan memelihara kehidupannya, mengelolah alam semesta, sebagaimana firman Allah swt dalam al Qur'an ${ }^{20}$ Manusia dalam kehidupannya di dunia memerlukan kebutuhan untuk kelangsungan keturunannya, laki-laki dan perempuan telah ditakdirkan untuk hidup bersama dalam sebuah masyarakat. Interaksi keduanya akan terciptanya kelangsungan hidup manusia di bumi.

Untuk merealisasikan keberlangsungan manusia ini, Islam menetapkan metode, yaitu perkawinan. ${ }^{21}$ Pengambaran penciptaan laki-laki dan perempuan sebagai pasangan hidup lalu melahirkan anak-anak sebagai kelanjutan keturunan, ${ }^{22}$ Pandangan Islam akan kebersamaan laki-laki dengan perempuan

\footnotetext{
${ }^{19} \mathrm{Ibid}$

${ }^{20}$ al Qur'an Surat al Baqarah ayat 30

${ }^{21}$ Penjelasan tentang perkawinan ini sudah dijelaskan dalam sub bab sebelumnya dalam desertasi ini.

${ }^{22} \mathrm{Al}$ qur'an surat an Nisa' ayat 1. Maksud dari padanya menurut jumhur mufassirin ialah dari bagian tubuh (tulang rusuk) Adam a.s. berdasarkan hadis riwayat Bukhari dan Muslim. di
} 
dalam ikatan perkawinan adalah suci, mulia sebagai penghormatan diri, disamping dapat mewujudkan ketenangan hidup serta dapat memenuhi kebutuhan manusia dalam keberlangsungannya. ${ }^{23}$ Perbedaan boleh saja dalam hal pengusaan dan peran, namun dari segi penilaian tentang ibadah itu tetap sama. Islam selalu mengikuti fitrahnya dalam membagi tugas-tugas laki-laki dan perempuan, lalu memberikan keistimewaan masing-masing, untuk menyandarkan tugas-tugas tertentu kepada masing-masing. Bukan untuk memberikan perhitungan khusus karena jenis kelaminnya melainkan memper pertimbangkan kehidupan kemanusiaan yang ditegakkan, diatur oleh kekhususa, dengan diwujudkan tujuannya, seperti menjadi pemimpin di muka bumi ini. Dan beribadah kepada Allah swt sesuai dengan kekhususannya masing-masing dan juga variasi fungsinya dalam memenuhi kehidupan. ${ }^{24}$ Hubungan laki-laki dan perempuan merupakan kenyataan bahwa keduanya saling dapat membangkitkan naluri seksual. Petemuannya dalam kehidupan bermasyarakat merupakan kebutuhan yang sangat dibutuhkan, Apabila kedunya menempati kedudukan sesuai tabiatnya, maka tujuan hidup untuk beribadah kepadanya dapat terlaksana dengan sehat dan, ${ }^{25}$

Sebagai landasan dan hukum-hukum syari'at, Al qur'an maupun sunnah mengandung nilai akhlak yang luhur, yang memandang manusia, yang memiliki naluri, perasaan, kecendrungan, serta akal. Sehingga dapat mendorong kokohnya manusia dalam kehidupan. ${ }^{26}$ Peran yang diberikan itu kadang kala sama dan adakalanya berbeda. ${ }^{27}$ Pertama, secara umum, Islam memandang lakilaki dan perempuan sebagai sasaran taklifi tanpa membedakan kedudukan keduanya dari sisi kelamin. Laki-laki dan perempuan mempunyai potensi yang sama dari segi insaniya, sehingga syari'at Islam memberikan status hukum yang sama bagi laki-laki dan perempuan dalam berprilaku atau bertinda, tindakannya itu kadangkala mubah, makruh, wajib, sunnah dan haram. Kesamaan itu dapat dilihat dalam al-Qur'an ${ }^{28}$ laki-laki dan perempuan sama-sama mempunyai kewajiban mengajak pada kebaikan, berakhlak muliah dan mencegah

samping itu ada pula yang menafsirkan dari padanya ialah dari unsur yang serupa Yakni tanah yang dari padanya Adam a.s. diciptakan. Menurut kebiasaan orang Arab, apabila mereka menanyakan sesuatu atau memintanya kepada orang lain mereka mengucapkan nama Allah seperti :As aluka billah artinya saya bertanya atau meminta kepadamu dengan nama Allah. Selain dalam surat an Nisa ayat 1 ada dalam surat An Nahal ayat 72, Asy-Syuura ayat 11, dan An Naba' ayat 8 .

${ }^{23}$ Al Qur'an surat al A"raaf ayat 189 dan ar Ruum ayat 21

${ }^{24}$ Sayyid Quthb, Op., Cit., h. 347

25 al Qur'an Adz Dzaariyat ayat 56

26 Anggota keluarga itu terdiri dari suami, istri, anak dan bahkan ibu.

27 Siti Muslikhati, Feminisme dan pemberdayaan perempuan dalam Timbangan Islam, (Jakarta; Gema Insani, 2014) 118-123

28 Al Qur'an surat Al A'raaf ayat 158 dan surat Saba' ayat 28. Dan yang kemudian Rasulullah dalam hadisnya menjelaskan bahwa sesungguhnya kaum perempuan adalah setara dengan kaum laki-laki. Hr Abu Daud dan an Nsa'i. As San'ani, Sulussalam. Op. cit,. 
kemungkaran, tanpa harus bertentangan satu dengan yang lainnya. ${ }^{29}$ Tatkala Allah swt membedakan tabiat laki-laki dan perempuan, maka keduanya dibebabani hak dan kewajiban yang berbeda pula, baik dengan fungsi, kedudukan maupun posisi dalam masyarakat. Sedangkan secara khusus perbedaan itu ditunjukan pada keberadaan keduanya. Seperti dalam hal berpakaian, mengingat aurat perempuan berbeda dengan laki-laki, laki-laki dibebani pemberian mahar, sedangkan perempuan dibebani penyusuan dan lainnya.

Istri pencari nafkah utama yang telah mengambil alih kewajiban suami maka sang istri berhak untuk menjadi pemimpin yangberkuasa terhadap pengaturan keuangan dalam rumah tangga bahkan harus diberikan hak berpendapat. Dalam hal ini suami harus bijaksana dan ihklas memberikan tongkat kepemimpinan dalam rumah tangga pada istrinya lalu suami juga harus mendukung sang istri, walau istri berkedudukan sebagai pemimpin dalam rumah tangga namun si istri tidak boleh mengabaikan prinsip bermusyawarah dalam menyelesaikan perkara rumah tangga, artinya kerjasama harus tetep di kedepankan.

\section{Konstruksi Kepemimpinan Dalam Rumah Tangga Yang Istri Sebagai Pencari Nafkah Utama dalam Bingkai Pemahaman Hukum Islam dan Hukum Positif}

Untuk memahami konstuksi kepemimpinan dalam rumah tangga istri pencari nafkah utama di kota Bengkulu dalam perspektif hukum, baik hukum Islam maupun hukum positif, peneliti akan menguraikan melalui ketiga unsur tersebut, yakni

\section{a. Subtansi (kontstruksi)}

Dari data yang di dapat baik dari hasil wawancara maupun observasi di lapangan diketahui bahwa istri pencari nafkah utama bagi keluarganya sedangkan posisi kepemimpinan dalam rumah tangganya ditangan suaminya, istri diperlakukan seperti ATM (sumber keuangan) yang tidak mempunyai kuasa apapun baik dalam mempergunakan uang ataupun berpendapat. Situasi seperti ini memang bersifat kasuistik dan universal namun sangat bertentangan dengan prinsip kalau suami istri itu harus saling melindungi dan menjadi mitra yang baik serta saling bermusyawarah dalam segala hal urusan dalam rumah tangga kondisi ini dipengauhi oleh sistem kekeluargaan yang dianut oleh masyarakat Bengkulu yakni sistem patrilineal, pengetahuan agama dan pola pergaulan yang sempit sehingga pengalaman tidak terserap dengan baik.

29 Informasi-informasi tentang kesamaan yang diserukan oleh Allah swt ini terdapat dalam Al Qur'an surat n Nisa' ayat 1, Al Ahzab ayat 36, Al A'raaf ayat 158, al Anfaal ayat 24, 1 Baqara ayat 183, 110 dan surat an Nur ayat 30-31 
Subtansi kepemimpinan terpusat hanya pada suami sedangkan suami tidak maksimal menjalankan kewajibannya untu memenuhi nafkah kepada istri dan anak-anaknya seperti ini bukanlah perbuatan yang bijak dan yang pada akhirnya akan membawa pada perbuatan haram, sebab hak akan didapat jika kewajiban dipenuhi. Nafkah merupakan kewajiban suami terhadap istri dan anaknya, suami harus berusaha semaksimal mungkin untuk memenuhi kebutuhan keluarganya khususnya istri dan anaknya, suami wajib memberi nafkah kepada istrinya dan bisa juga diartikan bekal hidup sehari-hari.

Konsep hubungan suami istri yang ideal adalah konsep kemitraan dan kesejajaran atau bisa disebut dengan setara, sebagaimana dalam firman Allah swt Al- Qur'an ${ }^{30}$ Lalu dalam firmanNya ${ }^{31}$ yang lain dinyatakan

Islam memberikan perbedaan dengan makna distinction bukan perbedaan dengan makna discrimination antara laki-laki dan perempuan, hal tersebut didasarkan pada kondisi objektif dan fisik-biologis keduanya. Islam tidak mengakui adanya diskriminasi peran antara laki-laki dan perempuan baik di lapangan pendidikan, ekonomi, sosial maupun politik. Oleh karena itu laki-laki dan perempuan harus mendapatkan dan diberikan porsi yang sama dalam menunaikan kewajiban dan mendapatkan hak. Konsep kesetaraan mengandung isyarat penerimaan martabat suami dan istri dalam ukuran yang sama dan juga suami dan istri mempunyai hak-hak yang setara dalam bidang sosial, ekonomi dan politik.

Behavioral difference antara laki-laki (suami) dan perempuan (istri) yang socially contsructed merupakan perbedaan yang bukan kodrat melainkan diciptakan oleh laki-laki dan perempuan itu sendiri melalui proses sosial dan budaya yang panjang dan bukan sekedar biologis namun sosial kultur. ${ }^{32}$ Sehingga kekerasan baik fisik maupun no fisik di dalam rumah tangga bahkan mungkin di lingkup negara kerap terjadi. Pemahaman tentang istri harus selalui menyenangkan suami, melayani suami, mematuhi suami dan menerima nafkah sesuai kemauan suami merupakan pemahaman yang sesat dan menyesatkan bagi istri. Dalam rangka menghapus diskriminasi dan meningkatkan status atau derajat perempuan di Indonesia maka dalam Undang-Undang Dasar tahun 1945 pasal 27 mengakui adanya asas persamaan. ${ }^{33}$ Dan bisa dilihat dalam al-Qur'an ${ }^{34}$

\footnotetext{
${ }^{30}$ Al- Qur'an surat Al- Baqarah ayat 187

31 Al- Qur'an surat Al- Nisa' ayat 124

32 Husein Muhammad, Fiqh Perempuan, (Yogyakarta; Pt lKis, Pealngi Aksara, 2017) h. $7-8$

33 Ayat 1 menyatakan bahwa tiap-tiap warga negara bersamaan kedudukannya di dalam hukum dan pemerintahan wajib menjungjung hukum dan pemerintahan itu dengan tidak ada kecualinya, dalam pasal ini mengandung arti bahwa " Hak untuk diperlakukan yang sama di dalam hukm dan pemerintahan dan kewajiban menjunjung tinggi hukum dan pemerintahan".

${ }^{34}$ Al- Qur'an Al Ahzab: 35
} 


\section{b. Struktur (Undang-undang dan Nas/Hukum Islam)}

Kenyataan di masyarakat bahwa sipencari nafkah utama dalam rumah tangga adalah istri sedangkan pemimpin rumah tangganya adalah suami merupakan situasi yang terbalik dan bertentangan dengan ajaran baik dalam Islam maupun dalam peraturan perudang-undangan yang berlaku di negara Indonesia. Dalam Islam dan peraturan perundang-undangan yang berlaku di negara Islam dinyatakan bahwa Menurut pemahman fiqh dan peraturan perundang undangan tentang perkawinan yang berlaku di Indonesia bahwa suami adalah pemimpin dan kepala keluarga yang mempunyai kewajiban yang meliputi, mencari nafkah, menguasai harta, pembimbing istri dan anak-anaknya, mengenai urusan rumah tangga diputuskan oleh suami sebab suami yang mencari nafkah dan mengatur keluarga ${ }^{35}$ melindungi anggota keluarga sehingga keluarga merasa nyaman dan aman. Peraturan perundang-undangan yang berlaku di Indonesia ${ }^{36}$ juga menyatakan bahwa suami adalah kepala keluarga dan istri ibu rumah tangga, hak dan kedudukan istri adalah seimbang dengan hak dan kedudukan suami dalam kehidupan rumah tangga dan pergaulan hidup bersama dalam rumah tangga. Kedudukan suami sebagai pemimpin, penguasa dalam harta bagi istri dan anak-anaknya dan pelaksana segala urusan wanita dikarenakan suami atau laki-laki mempunyai kelebihan baik kelebihan yang bersifat hakiki, seperti kemampuan berfikir dan kemampuan fisik, maupun kelebihan bersifat syar'i seperti kelebihan dalam menerima warisan. Dalam peraturan perundang-undangan pasal 105 dijelaskan bahwa suami merupakan kepala keluarga dalam persatuan suami istri, setiap suami harus mengemudikan urusan harta kekayaan milik pribadi istrinya, kecuali ada perjanjian lainya. Pasal 106 dinyatakan bahwa setiap istri harus tunduk dan patuh pada suaminya. ${ }^{37}$ Oleh karena itu kepemilikan dan kekuasaan harta oleh suami dikarenakan suami mempunyai kepemilikan terhadap nafkah.

Perudang-undangan di Indonesia, menjelaskan bahwa suami istri harus mempunyai tempat tinggal, suami wajib melindungi istrinya dan memberikan segala sesuatu yang masuk katagori keperluan hidup berumah tangga sesuai dengan kemampuannya, sebagaimana tercantum dalam peraturan perundangundangan ${ }^{38}$ yang menyatakana bahwa suami istri harus mempunyai tempat kediaman yang tetap, rumah tempat kediaman yang dimaksud ditentukan oleh suami istri bersama. Suami wajib melindungi istrinya dan memberikan segala sesuatu kepentingan hidup berumah tangga sesuai dengan kemampuannya. Lalu

35 Undang-undang No 1 Tahun 1974 dan Kompilasi Hukum Islam pasal 79 dinyatakan bahwa suami adalah kepala keluarga dan istri ibu rumah tangga.

${ }^{36}$ Kompilasi Hukum Islam pasal 79 ayat 1 dan 2

37 Subekti, R Tjitrosudibio, Kitab Undang-Undang Hukum Perdata, Burgerlijk Wetboek dengan tambahan Undang-undang Pokok Agraria dan Undang-undang Perkawinan, (Jakarta, Pt Pradnya Paramita, 1992) pasal 105-106

${ }^{38}$ Undang-undang No 1 tahun 1974 tentang perkawinan pasal 32 ayat 1 dan pasal 35 ayat 1 
pada aturan ${ }^{39}$ yang menjelaskan bahwa Suami wajib melindungi istri dan memberikan segala sesuatu keperluan hidup berumah tangga sesuai dengan kemampuannya, suami wajib memberi pendidikan agama kepada istrinya dan memberi kesempatan belajar pengetahuan yang berguna lagi bermanfaat bagi agama, nusa dan bangsa. Suami wajib menyediakan tempat kediaman bagi istri dan anak-anaknya atau bekas istri yang masih dalam masa iddah. Tempat kediaman adalah tempat tinggal yang layak untuk istri selama dalam ikatan perkawinan atau dalam iddah talak atau iddah wafat. Tempat kediaman disediakan untuk melindungi istri dan anak-anaknya dari gangguan pihak lain, sehingga mereka merasa aman dan tentram. Suami wajib melengkapi tempat tinggalnya, baik berupa alat perlengkapan rumah tangga maupun sarana penunjang lainnya. ${ }^{40}$

Kewajiban-kewajiban ini harus diimbangi dengan pemberian hak kepadanya, seperti berbakti lahir dan batin kepada suami dalam batas-batas yang dibenarkan oleh hukum Islam, istri menyelenggarakan dan mengatur keperluan rumah tangga sehari-hari dengan sebaik baiknya. ${ }^{41}$ Salah satu bentuk patuh atau berbakti adalah dengan meminta ijin jika hendak bepergian dan bukan sebaliknya, istri merupakan pendamping suami, ${ }^{42}$ istri wajib menjaga diri dan harta suami ${ }^{43}$ dan keduanya mempunyai hak yang sama dalam melakukan perbuatan hukum, sebagaimana firman Allah swt ini.

Dan Para wanita mempunyai hak yang seimbang dengan kewajibannya menurut cara yang ma'ruf. akan tetapi Para suami, mempunyai satu tingkatan kelebihan daripada isterinya dan Allah Maha Perkasa lagi Maha Bijaksana.

Jadi suami dibebani tugas sebagai pemimpin keluarga, rumah tangga bukan hanya kebendaan melainkan berupa tenaga dan suami juga sebagai penjaga kehormatan keluarga, oleh karena itu undang-undang yang berlaku di Indonesia menjelaskan bahwa kewajiban suami memberikan tempat tinggal dan biaya hidup kepada masing-masing istri secara berimbang menurut besar kecilnya jumlah keluarga yang ditanggung masing masing istri, kecuali jika ada perjanjian lain dalam perkawinan. ${ }^{44}$ Suami sendiri yang harus mengurus harta

\footnotetext{
${ }^{39}$ Kompilasi Hukum Islam pasal 80-81

${ }^{40}$ Ibid pasal 82

${ }^{41}$ Kompilasi Hukum Islam pasal 83 ayat 1-2

42 Undang-undang no 1 tahun 1974 tentang perkawinan pasal 30-34

${ }^{43}$ Khairuddin, Hukum Perkawinan I,(Yogyakarta, ACAdeMIA+TAZZAFA, 2013), h.

44 Kompilasi Hukum Islam pasal 82
} 
kekayaan bersama, ia diperbolehkan menjual dan memindah tangankan tanpa campur tangan istri. ${ }^{45}$

Kewajiban keduanya meliputi, saling cinta mencintai, hormat menghormati setia dan memberi bantuan lahir batin, mengasuh dan memelihara anak-anak, baik jasmani maupun rohani, pendidikan, kecerdasan, dan kehormatan. Perundang-undangan menjelaskan ${ }^{46}$ bahwa suami istri memikul kewajiban yang luhur untuk menegakkan rumah tangga yang sakinah, mawadda, warahmah yang menjadi sendi dasar dari susunan masyarakat. Suami istri wajib saling cinta mencintai, hormat menghormati, setia dan memberi bantuan lahir batin yang satu kepada yang lain. suami istri memikul kewajiban untuk mengasuh dan memelihara anak-anak mereka, baik mengenai pertumbuhan jasmani, rohani maupun kecerdasan dan pendidikan agamanya, suami sitri wajib menjaga kehormatannya, jika keduanya melalaikan kewajibannya masing-masing dapat mengajukan gugatan kepada pengadilan agama. Suami istri memikul kewajiban yang luhur untuk menegakkan rumah tangga, pergaulan hidup bersama dalam masyarakat, kedua suami istri mempunyai hak dan kedudukan yang seimbang baik dalam rumah tangga maupun dalam masyarakat. Keduanya sama-sama mempunyai hak melakukan perbuatan hukum, istri merupakan pendamping Suami. ${ }^{47} \mathrm{Dalam}$ pasal 40 ayat $3^{48}$ dinyatakan bahwa perjanjian yang demikian tidak boleh mengurangi segala hak yang disandarkan kepada kekuasaan suami sebagai kepala persatuan harta suami dan istri, kecuali namun ini, bahwa berhaklah si istri memperjanjikan bagi dirinya, akan mengatur sendiri

45 Pasal 24 KUHP Perdata. Dalam pasal 40 perjanjian yang demikian tidak boleh mengurangi segala hak yang disandarkan kepada kekuasaan suami sebagai kepala persatuan harta suami dan istri, kecuali namun ini, bahwa berhaklah si istri memperjanjikan bagi dirinya, akan mengatur sendiri urusan harta kekayaannya pribadi, baik bergerak maupun tak bergerak, dan akan meninkmati sendiripula dengan bebas pendapatannya secara pribadi. Dalam Kompilasi Hukum Islam kekuasaan suami diatur dalam pasal 89 "Suami bertanggung jawab menjaga harta bersama, harta istri maupun hartanya sendiri" Pasal 90 "Istri turut bertanggung jawab menjaga harta bersama maupun harta suami yang ada padanya. Pasal 92 "Suami atau istri tanpa persetujuan pihak lain tidak diperbolehkan menjual atau memindahkan harta bersama" dan pasal 93 "pertanggungjawaban terhadap hutang suami atau istri dibebankan pada hartanya masing-masing. Petanggungjawaban terhadap hutang yang dilakukan untuk kepentingan keluarga, dibebabankan kepada harta bersama, bila harta bersama tidak cukup, dibebankan kepada harta suami, dan bila harta suami tidak cukup atau tidak ada dibebankan kepada harta istri.

${ }^{46}$ Kompilasi Hukum Islam pasal 77 ayat 1-5 "Suami istri memikul kewajiban yang luhur untuk menegakkan rumah tangga yang sakinah, mawadda, warahmah yang menjadi sendi dasar dari susunan masyarakat. Suami istri wajib saling cinta mencintai, hormat menghormati, setia dan memberi bantuan lahir batin yang satu kepada yang lain. suami istri memikul kewajiban untuk mengasuh dan memelihara anak-anak mereka, baik mengenai pertumbuhan jasmani, rohani maupun kecerdasannya dan pendidikan agamanya, suami sitri wajib menjaga kehormatannya, jika keduanya melalaikan kewajibannya masing-masing dapat mengajukan gugatan kepada pengadilan agama.'

47 Undang-undang no 1 tahun 1974 tentang perkawinan pasal 30-34

48 Ibid. 
urusan harta kekayaannya pribadi, baik bergerak maupun tak bergerak, dan akan meninkmati sendiripula dengan bebas pendapatannya secara pribadi.

Dalam Kompilasi Hukum Islam kekuasaan suami diatur dalam pasal 89"Suami bertanggung jawab menjaga harta bersama, harta istri maupun hartanya sendiri" pasal 90“Istri turut bertanggung jawab menjaga harta bersama maupun harta suami yang ada padanya. Pasal 92 suami atau istri tanpa persetujuan pihak lain tidak diperbolehkan menjual atau memindahkan harta bersama dan pasal 93 pertanggungjawaban terhadap hutang suami atau istri dibebankan pada hartanya masing-masing. Petanggungjawaban terhadap hutang yang dilakukan untuk kepentingan keluarga, dibebabankan kepada harta bersama, bila harta bersama tidak cukup, dibebankan kepada harta suami, dan bila harta suami tidak cukup atau tidak ada dibebankan kepada harta istri. Apa yang menjadi kewajiban suami merupakan hak bagi istri, baik berhak materil ${ }^{49}$ seperti istri berhak mendapatkan mahar dan nafkah ataupun non materil seperti hubungan baik, perlakuan yang baik dan keadilan. Lalu apa yang menjadi kewajiban dari istri merupakan hak bagi suami. Istri mempunyai hak yang seimbang dengan kewajibannya. Semua hal yang menjadi kebiasaan yang patut, ${ }^{50}$ merupakan kewajiban bagi kedua belah pihak. Patut yang dimaksud adalah sesuai dengan hukum Islam, memperhatikan secara khusus terhadap keluarga itu juga merupakan kewajiban. Keduanya harus memperlakukan yang lain dengan penuh kebaikan, dan menahan aniaya. Keberadaan hak Suami dan hak istri juga dibicarakan dalam hadis ${ }^{51}$.

Orang yang paling baik diantara kalian adalah orang yang paling baik memperlakukan keluarganya, dan akau adalah orang yang paling baik memperlakukan keluargaku..

Orang mukmin yang paling sempurna keimanannya adalah orang yang paling baik akhlaknya, dan yang paling baik kepada istrinya.

Dari paparan itu difahami bahwa suami mempunyai kewajiban dan hak, yang mana kewajiban suami merupakan hak bagi istri dan hak suami merupakan kewajiban bagi istri. Dalam melaksanakan kewajiban baik suami maupun istri

49 Pemahaman ini terambil dari firman Allah dalam surat Al Baqarah ayat 233 "Dan kewajiban ayah memberi makan dan pakaian kepada para ibu dengan cara ma'ruf. dan juga hadist nabi" kami berikan dia makan jika kamu makan, kamu pakaikan dia jika kamu mengenakan pakaian. dan jangan kamu pukul wajahnya, dan jangan kamu buat dia menjadi buruk, jangan kamu tinggalkan dia kecuali di dalam rumah. Al Qawaaniinu al Fiqhiyyah. h, 213 dan Wahbah az Zuhaili, al Fiqh al Islamy., Op., Cit., h. 294

${ }^{50}$ Sebagaimana firman Allah swt " pergaulilah mereka secara patut”. Al Qur'an surat An Nisa' ayat 19

51 Asy Syarhush Shaghiir. h. 459-463 dan juga Al Bada’i., Op. Cit . h. 302-304 
harus memperhatikan hak. Hak dan kewajiban harus berjalan dengan seimbang, kewajiban ada karena adanya hak dan hak itu harus mereka terima. Allah swt menciptakan kedua jenis kelamin ini tidak mungkin berbuat zalim terhadap salah satunya, Islam memberikan pengaturan, pembagian peran, tanggung jawab dalam kanca kehidupan secara adil dan harmonis. sedemikian itu dapat difahami dari rahasia dibalik penciptaan laki-laki dan perempuan. ${ }^{52}$

Aturan interaksi laki-laki dan perempuan ini sangat dibutuhkan manusia, sebab manusia mempunyai suatu fitrah yang khas dibanding makhluk yang lain. Kedua jenis ini tidak dapat dibedakan dari aspek kemanusiaannya, oleh karenanya Allah Swt dalam penciptaannya telah menganugerahkan akan potensi dinamis sebagai kebutuhan hidup baik berupa dorongan jasmani, seperti lapar, dan potensi naluria atau insting seperti mempertahankan diri. Selain itu Allah swt juga memberikan manusia kekuatan untuk berfikir yakni akal yang ada pada perempuan ataupun laki-laki, dengan akal manusia dapat melakukan pilihanpilihan sekaligus mencapai efektivitas kesempurnaan hidup. Perempuan dan laki-laki diciptakan Allah swt sebagai mitra yang saling membutuhkan sebab tidak mungkin seorang perempuan merasa tidak butuh kepada laki-laki sebagai mendampinginya meskipun si perempuan mempunyai kedudukan yang tinggi, harta yang melimpah ataupun intelektual yang tinggi. Begitu juga seorang lakilaki tidak mungkin tidak membutuhkan perempuan yang mendampinginya. Nabi bersabda berikut ini;

Sesungguhnya, dunia ini adalah perhiasan dan sebaik-baiknya perhiasan adalah perempuan yang membantu suaminya untuk mewujudkan kebahagiaan diakhirat. Sungguh kasihan seorang laki-laki yang tidak memiliki istri. sungguh kasihan bagi perempuan yang tidak memiliki suami. $^{53}$

Kasihan sungguh kasihan laki-laki yang tidak mempunyai istri., lalu berkatalah sahabat; Walaupun dia banyak harta. Rasulullah menjawab, walaupun dia mempunyai harta yang banyak. Dan kasihan.. kasihan seorang perempuan yang tidak mempunyai suami, lalu shahabat juga bertanya; walaupun dia kaya, Rasulullah menjawab walaupun dia memiliki harta yang banyak. ${ }^{54}$ Penetapan hak dan kewajiban suami istri sangat erat hubungannhya dengan kemaslahatan manusia, ${ }^{55}$ Allah swt

\footnotetext{
${ }^{52}$ Pengaturan pembagian peran nampak jelas pada peran suami dan istri dalam keluarga, dapat juga dilihat dari hak dan kewajiban suami dan istri.

53 HR. Ibnu Majah., Sunan ibnu Majah, (Beirut; Dar al Fikr, TTh) jiuj 1., h. 592

${ }^{54}$ Ibid.,

${ }^{55}$ Abdul Qadim Zallum, Konspirasi Barat Meruntubkean Khalifah Islamiyah, (Bangil; al Izzah, 2001), h. 1-20
} 
telah memerintahkan kepada laki-laki dan perempuan untuk bersikap ridho terhadap pengkhususan salah satu pihak. ${ }^{56}$

Peran yang diberikan itu kadang kala sama dan adakalanya berbeda. ${ }^{57}$ Pertama, secara umum, Islam memandang laki-laki dan perempuan sebagai sasaran taklifi tanpa membedakan kedudukan keduanya dari sisi kelamin. lakilaki dan perempuan mempunyai potensi yang sama dari segi insaniya, sehingga syari'at Islam memberikan status hukum yang sama bagi laki-laki dan perempuan dalam berprilaku atau bertinda, tindakannya itu kadangkala mubah, makruh, wajib, sunnah dan haram.

\section{c. Kultur ('urf dan maslahan mursalah)}

Kemaslahatan yang dikehendaki syari' dalam rangka mewujudkan dan menjaga tujuan hukum, menciptakan kemaslahatan ummat. ${ }^{58}$ Jadi Maslahah mursalah itu segala hal yang bersesuaian dengan tujuan-tujuan syariah Islam walaupun tidak ditopang oleh dalil yang khusus baik bersifat melegitimasi atau membatalkan maslahat tersebut. ${ }^{59}$ Teori maslahah mursalab menurut Muslehuddin terikat pada konsep tujuan syarīat dalam rangka menjaga kepentingan masyarakat dan berfungsi memberikan kemanfaatan serta menghilangkan kemudharatan bagi masyarakat. ${ }^{60}$

Memperlakukan istri sebagai pemimpin dalam rumah tangga manakalah si istri merupakan pencari nafkah utama, dan memberikan "kekuasaan" dalam mengelolah dan mempergunakan harta yang ada namun, keberadaan suami walau dia bukan pemimpin karena dia bukan pencari nafkah namun suami tidak boleh diremehkan, suami istri harus bermusyawarah dalam memutuskan apa yang diperlukan dalam rumah tangga. Lima jaminan dasar kemaslahatan itu

56 Al Qur'an surat An Nisa' ayat 32. Asbabunuzul dari ayat ini adalah bahwa Ummu Salamah berkata, kaum laki-laki berperang, sedang wanita tidak, dan kita hanya mendapatkan setengah bagian warisan laki-laki, dalam persi lain dinyatakan bahwa ada seorang wanita yang mengadu kepada Nabi dengan mengatakan, ya Nabi laki-laki mendapatkan dua bagian dari kaum perempuan dalam warisan dan dua orang saksi perempuan sama dengan satu orang saksi laki-laki, apakah dalam beramalpun demikian..?. Maka Allah turunkan ayat ini sebagai penjelasan bahwa laki-laki dan perempuan mendapatkan imbalah yang sama sesuai dengan amal ibadahnya. Dahlan, et. al, Asbabun Nuqul Latar belakang Historis turunnya Ayat -ayat Al Qur'an, (Bandung; Diponogoro, Tth) h 129

${ }^{57}$ Siti Muslikhati, Feminisme dan pemberdayaan perempuan dalam Timbangan Islam, (Jakarta; Gema Insani, 2014) 118-123

58 Abdul Wahab Khalaf, Ilmu Ushrũl Figh, Ali Bahasa, KH. Masdar Helmy (Bandung: Gema Risalah Press, 1997), h. 142

${ }^{99}$ Muh Abu Zahrah, Ushĩul Fiqh, Penerjemah, Saefullah Ma’sum, Dkk (Jakarta; Pustaka Firdaus, 1994) h 427

${ }^{60}$ Muhammad Muslehuddin, Philosophy of Islamic Law and The Orientalis A Camparativ Study of Islamic Legal System alih bahasa Wahyudi Asmin, (Yogyakarta; Tiara Wacana, 1991), h. 127 
adalah keselamatan keyakinan (agama), keselamatan jiwa, keselamatan akal (kehormatan), keselamatan keluarga, keselamatan keturunan, dan ke selamatan harta benda. Kelima jaminan dasar ini selaras dengan maqäsid as-syariah, yakni untuk memelihara lima rukun kehidupan manusia yaitu memelihara agama, akal, keturunan, harta, dan jiwa. ${ }^{61}$

Memberikan hak kepemimpinan dalam rumah tangga kepada yang bertanggungjawab atas nafkah dalam hal ini adalah istri karena dia yang memberikan nafkah pada keluarganya adalah syah dan hukumnya wajib demi kemaslahatan baik kemaslahatan agama, akal, jiwa, harta dan keturunan. Adapun dasar hukum yang menjadi alasan bahwa setiap hukum harus mengandung maslahat bagi manusia adalah Al-Qurãn. ${ }^{62}$ Suami istri merupakan mitra yang saling membutuhkan walapun mempunyai kedudukan yang berbeda.

\section{Penutup}

Setelah peneliti menghimpun data dan menganalisa hasil penelitian dengan menghubungkannya ke beberapa teori maka sampailah peneliti pada titik penarikan kesimpulan. Adapun kesimpulan dari penelitian ini adalah:

1. Mayoritas masyarakat belum memahami bahwa kepemimpinan dalam rumah tangga merupakan hak bagi yang bertanggungjawab terhadap nafkah.

2. Istri pencari nafkah harus mendapatkan pembagian harta yang lebih banyak dari suami yang bukan pencari nafkah utama.

3. Konstruksi kepemimpinan dalam rumah tangga yang istri sebagai pencari nafkah utama idealnya diberikan kepada yang bertanggungjawab atas nafkah dan itu syah dan hukumnya wajib demi menjaga kemaslahatan baik kemaslahatan agama, akal, jiwa, harta dan keturunan.

\section{Daftar Pustaka}

Al Qur'an

Abdul Qadim Zallum, Konspirasi Barat Meruntuhkan Khalifah Islamiyah, (Bangil; al Izzah, 2001

Abdul Wahab Khalaf, Ilmu Ushữl Fiqh, Ali Bahasa, KH. Masdar Helmy (Bandung: Gema Risalah Press, 1997),

${ }^{61}$ Kelima unsur ini (Daruriyyah) di isyaratkan oleh Allah swt dalam Al Qur'an surat al Mumtahanah ayat 12. Menurut para ahli Ushul walaupun ayat ini tertuju pada wanita, akan tetapi hal ini juga berlakup pada kaum pria. Tidak syirik; dalam rangka menjaga agama, tidak mencuri; dalam rangka menjaga harta, tidak berzina; dalam rangka menjaga keturunan dan kehormatan dan tidak membunuh dalam rangka menjaga jiwa.

62 Al-Qurãn Surat Al Nisã';165 
Amir Syarifuddin, Pembaharuan Pemikiran Hukum Islam, (Padang: Angkasa Raya, 1993),

As San'ani, Sulussalam.

Azyumardi Azra dan Abudin Nata, Kajian Tematik Al-Qur'an tentang Kemasyarakatan (Bandung: Angkasa, 2008)

Bisri Mustofa dan Elisa Vindi Maharani, Kamus Lengkap Sosiologi, (Jogjakarta; Panji Pustaka, 2008),

Dahlan, et. al, Asbabun Nuzul Latar belakang Historis turunnya Ayat ayat Al Qur'an, (Bandung; Diponogoro, Tth)

Departemen Pendidikan dan Kebudayaan, Kamus Besar bahasa Indonesia,(Jakarata; Balai Pustaka. 1988 1993),

Hilman Hadikusuma, Hukum Kekerabatan Adat, Jakarta: Fajar Agung,

Husein Muhammad, Fiqh Perempuan, (Yogyakarta; Pt IKis, Pealngi Aksara, 2017)

Khairuddin, Hukum Perkawinan I,(Yogyakarta, ACAdeMIA+TAZZAFA, 2013

Kompilasi Hukum Islam

M. Quraish Shihab, Tafsir Al-Mishbah Pesan, Kesan dan Keserasian Al-Qur'an

Muh Abu Zahrah, Ushữl Fiqh, Penerjemah, Saefullah Ma'sum, Dkk (Jakarta; Pustaka Firdaus, 1994)

Muhammad Muslehuddin, Philosophy of Islamic Law and The Orientalis A Camparativ Study of Islamic Legal System alih bahasa Wahyudi Asmin, (Yogyakarta; Tiara Wacana, 1991),

Siti Muslikhati, Feminisme dan pemberdayaan perempuan dalam Timbangan Islam, (Jakarta; Gema Insani, 2014)

Subekti, R Tjitrosudibio, Kitab Undang-Undang Hukum Perdata, Burgerlijk Wetboek dengan tambahan Undang-undang Pokok Agraria dan Undang-undang Perkawinan, (Jakarta, Pt Pradnya Paramita, 1992

Sunan ibnu Majah, (Beirut; Dar al Fikr, TTh) jiuj 1.,

Undang-undang No 1 Tahun 1974 dan

Undang-undang Nomor 10 Tahun 1992 tentang kependudukan dan Keluarga Sejahtera Bab Ketentuan Umum, 
96 | Manhaj: Jurnal Penelitian dan Pengabdian Masyarakat | Vol. 4 No. 1, 2019

W.J.S Poerwadarminta, Kamus Umum Bahasa Indonesia, Jakarta: Balai Pustaka, 1985

Wahbah az Zuhaili, al Fiqh al Islamy., 